\title{
COMMENTS ON NITROGEN EXCRETION FROM THE DIVER'S ORGANISM DURING THE REDUCED PRESSURE AT THE FINAL DECOMPRESSION STATION (<1 ATA)
}

Tadeusz Doboszyński, Bogdan Łokucijewski

Department of Maritime and Tropical Medicine of the Military Medical Academy

\section{ABSTRACT}

The authors discuss the effect of reduced pressure at the final decompression station on nitrogen excretion from the organism of a diver. The assumed basis for the said considerations was the course of decompression during dives performed in lakes located at a significant altitude above sea level and diver transportation by plane following dive completion. Based on the presented calculations the authors conclude that air transport can take place only upon the lapse of time calculated with regard to the diving conditions and the expected altitude of the flight. Diving in mountain lakes requires proper consideration of the effects of the decreased atmospheric pressure.

Key words: decompression, mathematical modelling, mountain diving, air transport.

ARTICLE INFO

PolHypRes 2016 Vol. 54 Issue 1 pp. 31-36

ISSN: $1734-7009$ elSSN: 2084-0535

DOI: $10.1515 / p h r-2016-0004$

Pages: 6, figures: 2 , tables: 0

page www of the periodical: www.phr.net.pl

Publisher

Polish Hyperbaric Medicine and Technology Society

\section{Original article}

Originally published in Bulletin of the Military Medical Academy number 31966

Date of approval for print in PolHyp Res: 20.01.2016r. 


\section{INTRODUCTION}

Rapid development of diving practices both among amateurs and professionals requiresspecial attention to be paid to the exceptional issues connected with decompression.

The safety margin provided in various diving tables tends to vary $[2,3,4,5,9,10,11]$, nonetheless it may be stated that it is relatively narrow. Thus, the safety range may prove inadequate, particularly in conditions where the diver manifestly deviates from the standards considered in the calculation and verification of tables; for example if the diver is obese $[6,7,10]$ or in conditions where the atmospheric pressure at the final station is lower than 1 ata.

In this case exposure to decompression sickness is conditioned by the presence of a proportionally higher quantity of dissolved gas in tissues as compared with the allowable quantities in the transition to the pressure lower than $1 \mathrm{~atm}$.

In view of the above considerations it is worth noting both the conditions of decompression in the case of diving in lakes located at significant altitudes above sea level as well as issues connected with possible diver transportation by plane once the dive is completed.

The benefits of discussing the above topic seems to be additionally supported by the fact that cases of transporting a sick diver by plane as well as cases of decompression sickness during diving in a lake located at the altitude of approximately $1500 \mathrm{~m}$ a.s.l. have already been reported in Poland.

Varied decompression courses in dives performed in lakes at a significant altitude thus far have not been discussed by Polish literature, whereas foreign publications pointed to this fact already a relatively long time ago [3, 8], finding a practical solution in recommendations to apply corrections in the used diving tables.

Namely, there is a noted relationship between Boyle and Mariotte's law and the diving depth, the depths of decompression stations and the pressure at the surface. As a result of this relationship, the diving depth corresponds to a greater equivalent depth, whereas the depths of particular decompression stations to smaller values, as it stems from the following formulas:

$$
h_{m}=\frac{\mathrm{m} \times \mathrm{Ho}}{H_{n}} \quad S_{m}=\frac{m \times H_{n}}{H_{o}}
$$

Where: $\mathrm{H}_{0}-760 \mathrm{~mm} \mathrm{Hg}$

$\mathrm{H}_{\mathrm{n}}-<760 \mathrm{~mm} \mathrm{Hg}$

$\mathrm{h}_{\mathrm{m}}$ - equivalent diving depth in metres

$\mathrm{S}_{\mathrm{m}}$ - equivalent depth of station in metres

A different kind of relationship is noted in the determination of the required desaturation time on the surface (upon diving completion) before transition to a reduced pressure.

Since the authors were not able to find interesting data concerned with desaturation during a stay on the surface, the presented theoretical assumptions were used in performing calculations anddetermining the required time of desaturation for a safe transition to the pressure corresponding to the altitudes of $500,1000, \ldots, 3000 \mathrm{~m}$.

\section{CALCUlation METHOD AND RESUlTS} tissue $120^{\circ}$

The calculations were conducted in relation to

The relationship between (additional) saturation and diving time and depth expressed in \% on the basis of calculations and numerical data resulting from French diving tables G.E.R.S. - II/8/fig.1

The semi-saturation curve of tissue $120^{\circ}$ was approximated with the mean squared method using polynomial degree $n=5$ (5)

The formula expressing the relationship $t=$ $\mathrm{F}\left(\mathrm{x}_{\mathrm{p}} \%\right)$ was given the following form:

$$
\sum_{i=0}^{n} a_{n}\left[1+\frac{100}{z} / p_{o}-k p\right]^{i}
$$

Where:

120 - tissue $120^{\circ}$ desaturation time

$\mathrm{n}$ - approximate polynomial degree

$a_{n}$ - approximated polynomial coefficient

$\mathrm{k}$ - tissue $120^{\circ}$ coefficient

$z-\%$ of (additional) desaturation of tissue $120^{\circ}$ with $P_{0}$

$\mathrm{p}_{\mathrm{o}}$ - atmospheric pressure above sea level in atm

$\mathrm{P}$ - atmospheric pressure at the altitude of $500,1000, \ldots, 3000 \mathrm{~m}$ in atm

Safe desaturation time charts are presented in fig. 2 . 


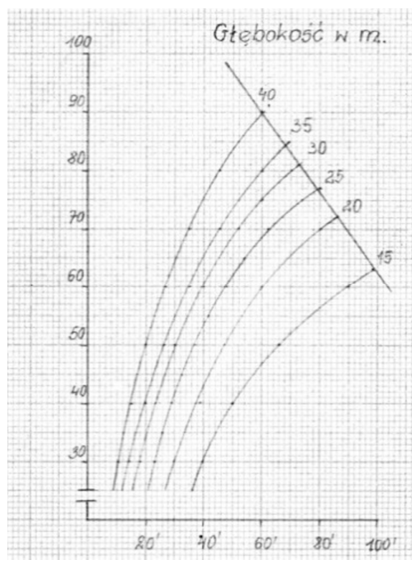

Fig. 1. Depth in $[\mathrm{m}]$

\section{DISCUSSION}

The graphs presented in fig. 1 and 2 identifies the desaturation time on the surface required before a diver can be transportated by air. However, it should be emphasised that the above values, being practically unverified, require particular caution in evaluation and should be treated as output data.

The basis of these calculations was found in the assumption that the desaturation time waslimited by tissues characterised by the longest semi-saturation period. According to data seen in literature, with regard to short-term diving, such tissues are: tissue 80 ' [11] and $120^{\circ}[8,11]$. And since with regard to both these tissues nearly the same coefficient is adopted, it seemed proper (following initial calculations) to select tissue $120^{\prime}$. For this reason, the graph presented in figure 1 was prepared on the basis of data resulting from the table G.E.R.S. - II.

The percentage of tissue $120^{\prime}$ saturation was calculated in relation to the upper permissible value of 100. Thus, $100 \%$ constitutes the upper safe limit of saturation with the pressure of $1 \mathrm{~atm}$.

As results from the chart, the \% of saturation with correctly performed decompression depends both on the depth and time of diving. For the above reason, particular depths are represented by separate curves.

The trajectory of particular curves depicts certain deviation from the values resulting from the tables (i.e. does not take the shape of steps), as they were performed on the basis of approximations with consideration of the highest values (continuous decompression, not gradual). Moreover, this type of solution takes into account the fact that the decompression time provided in the G.E.R.S.-II tables is relatively short, which in our opinion allows use of the graph in the situation when a diver operates on just about any decompression table.

Graph 2 presents curves of the necessary desaturation time on the surface enabling transition to the reduced pressure corresponding to the values between 500 and $3000 \mathrm{~m} \mathrm{[1].}$

Particular curves were designated for values resulting from fig. 1 with a coefficient of 2.0,1. The calculations were carried out in accordance with the assumption made in the previous work [5].

As stems from the chart, the curves designating the time limit for the necessary saturation depend on two

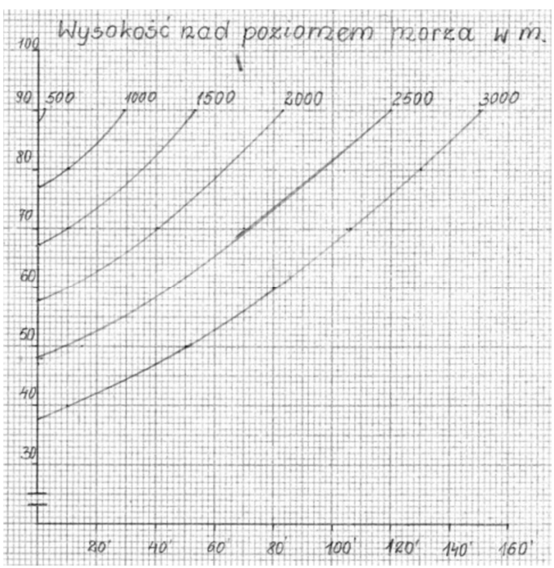

Fig. 2. Altitude above sea level in [m]

values - tissue desaturation and altitude above sea level Within the scope of the adopted values the highest desaturation occurs following diving completion and properly conducted decompression from the depth of 40 $\mathrm{m}$ after the time of $60^{\prime}$. In the above case, additional desaturation reaches $90 \%$.

The transition from such conditions to the pressure corresponding to the altitude of $3000 \mathrm{~m}$ requires $2 \mathrm{~h} 30$ ' of desaturation on the surface. An earlier transition to a reduced pressure elevates the risk of an occurrence of an episode of decompression sickness.

Therefore, the presented graphs allow to define the required period that should elapse before transportation by air in the conditions of reduced pressure.

Contrary to the considered conditions of the complex phenomenon of desaturation on the surface, determination of proper decompression conditions in performing dives in a mountain lake results from the following relationship: in dives conducted at lower altitudes, the first pressure duplication occurs at a depth of $10 \mathrm{~m}$, however at altitude, this duplication happens at a respectively smaller depth. With this regard, in the case of diving to a depth of $40 \mathrm{~m}$ above sea level in a lake located at the altitude of $1500 \mathrm{~m}$ a.s.l. the equivalent diving depth corresponds to the depth of $48 \mathrm{~m}$, whereas the equivalent depth of stations located at $6 \mathrm{~m}$ and $3 \mathrm{~m}$ falls at $5 \mathrm{~m}$ and $2.5 \mathrm{~m}$ respectively.

According to the provided data, it is always required to consider additional circumstances resulting from reduced pressure, as otherwise excessive saturation involves the risk of decompression sickness along with all its symptoms.

\section{Conclusions}

- In the case of necessity to transport a diver by plane after a completed dive it is required to first complete desaturation on the surface.

- Diving in the conditions of a decreased pressure on the surface requires taking into account its effect on the depth of diving and stations. 


\section{BIBLIOGRAPHY}

Armstrong H.G.: Aero-space medicine, The Williams \& Wilkins Company, Baltimore 1961;

Bogusławski W.: Theoretical considerations on the effect of pressure on human organism. Biul.Inst.Med.Mor.Trop. 6., 292,1955; Guillerme J.,Rivoire J.: Traité de Plongée, Dunod, Paris 1955;

Davis M.R.: Deep Diving and Submarine operations. The Saint Catherine Press, London 1951;

Doboszyński T.: Safe exit curve without stations as one of the factors for the analysis and calculation of diving tables. In printing

Dolatkowski A.: Collection of works published between 1929-1957. D-wo Mar.Woj. Gdynia 1957;

$Ł a b a \mathrm{~L}$.: The application of standard decompression norms in the prophylaxis of decompression sickness in divers. Evaluation of Polish Diving Tables. Biul. Inst. Med. Mor. Gdańsk nr 3/4 XV, 157, 1964;

Marine Nationale: La Plongee. Arthand 1961;

M.O.N. Przepisy Służby Nurkowej Mar. Woj. Gdynia 1964;

10. Submarine Medicine Practice. Washington 1955;

11. Workman R.D.: report No 11-57. N. Exp. Div. Unit. Washington D.C. 1957

Tadeusz Doboszyński

Department of Maritime and Tropical Medicine of the Military Medical Academy 